\title{
The Production of the Indian Student: \\ Regimes and Imaginaries of Migration, Education, Citizenship \\ and Class
}

\author{
Shanthi Robertson \\ Western Sydney University
}

\begin{abstract}
The so-called Indian student 'crisis' of 2009 and 2010 is often analysed in the context of how the violence against students challenged Australian multiculturalism and revealed both underlying racism and denial of racism in Australian society (see, for example, Mason 2012, Dunn, Pelleri \& Maeder-Han 2011, Singh 2011). Some analyses further interrogate the incidents in relation to Australia's relationship to India as one of its AsiaPacific neighbours and key trading partners (Mason 2012). Yet there was a far wider context of global transformations to regimes of immigration, education, labour and citizenship that shaped the experience of Indian students in Australia leading up to and after the 'crisis' itself. The local context and local responses to the crisis are analysed thoroughly elsewhere. What I seek to do in this paper is to situate the very presence (and the subsequent vulnerabilities) of Indian students in Australia within several intersecting political, economic and cultural forces operating at national, regional and global scales. The focus of this paper is thus not on the violent incidents or their immediate consequences, but rather on the specific ways that transforming immigration and citizenship regimes, global labour markets, and global imaginaries of mobility and class facilitated Indian students' mobility into Australia and shaped elements of their lives while they were here. In particular, I focus on how national mobility regimes, influenced by global processes, crafted and re-crafted the subjectivities of Indian students as by turns desirable and problematic.
\end{abstract}

\section{Introduction}

The so-called Indian student 'crisis' of 2009 and 2010 is often analysed in the context of how the violence against students challenged Australian multiculturalism and revealed both underlying racism and denial of racism in Australian society (see, for example, Mason 2012, Dunn, Pelleri \& Maeder-Han 2011, Singh 2011). Some analyses further interrogate the incidents in relation to Australia's relationship to India as one of its Asia-Pacific neighbours and key trading partners (Mason 2012). Yet there was a far wider context of global transformations to regimes of immigration, education, labour and citizenship that shaped the experience of Indian students in Australia leading up to and after the 'crisis' itself. The local 
context and local responses to the crisis are analysed elsewhere. What I seek to do in this paper is to situate the very presence (and the subsequent vulnerabilities) of Indian students in Australia within several intersecting political, economic and cultural forces operating at national, regional and global scales. The focus of this paper is thus not on the violent incidents or their immediate consequences, but rather on the specific ways that transforming immigration and citizenship regimes, global labour markets, and global imaginaries of mobility and class facilitated Indian students' mobility into Australia and shaped elements of their lives while they were here. In particular, I focus on how national mobility regimes, influenced by global processes, crafted and re-crafted the subjectivities of Indian students as by turns desirable and problematic. While I focus in this paper on the contemporary context, such processes of the subjectivity-making of the global, mobile Indian are neoliberal transmutations of ongoing historical processes. Pre-Federation and during the White Australia Policy, for example, South Asian migrants in Australian imaginaries occupied marginal positions as hawkers, peddler and cameleers, while from the post-White Australia 1970s they were largely seen as among the most highly skilled and highly educated of emerging ethnic communities (Foster and Foster 1999). The rapid influx of Indian students in the mid-2000s added a new layer to these historical imaginings of the mobile Indian.

The rapid increase in Indian students studying in Australia between 2004 and 2009 saw numbers jumping from less than 20,749 enrolments (6.5\% of the international student population) in 2004 to 109,356 enrolments (19\% of the international student population) in 2009 (Australian Education International 2009, as cited in Sploc \& Lee 2009), leading Indians to become the second largest national group of international students after the Chinese. And, just as imperial regimes of the past became dependent on the indentured labour that formed the foundation for the modern Indian diaspora, Australia's international education regime was increasingly reliant of the capital of Indian students. The series of violent attacks against Indian students in 2009 and 2010 and the subsequent protests in both Australia and India received large amounts of media attention in both countries. These events occurred alongside increasing criticism of the quality of international education provision in Australia. Several private colleges that enrolled Indians almost exclusively came under official investigation for breaches in training standards and allegations of immigration fraud. Both the violence and the regulatory 'crisis' in the education industry positioned Indian students as a highly visible segment of the student population, and a segment largely seen as distinct (in terms of their behaviours but also their vulnerabilities) from both international 
students of other nationalities, and from previous waves of Indian 'settler' migrants and second generation Indian-Australians. Indian students thus became a particular kind of 'problem population' in multicultural Australia, in turns portrayed in the media as 'victims' of racist violence and 'profiteers' of a corrupt migration industry (Baas 2014). The intense media coverage of Indian students and the visibility of their own protests and lobbying threatened Australia's branding as a 'safe and multicultural' destination for international students (International Education Association of Australia 2012a, 2012b, Knight 2011). Locally as well as transnationally, there was much discussion around whether the violence was wrought by embedded racism or mere criminal opportunism (ABC News 2009, Jamieson 2010).

Why, however, were so many Indian students in Australia at this time and why were their experiences of being here different from, or at least constructed as different from, other transnationally mobile groups? Why did international students in general, and Indian students in particular, go from being welcome sojourners and consumers in Australia to highly problematic subjects? In this paper, I seek to argue somewhat beyond the debates about the violence and racism at the national level. Instead, I seek to show that the Indian student 'crisis' was driven in a significant way by the shifting attempts of the Australian immigration regime to manage mobility and shape particular kinds of migrant subjects within a particular set of global transformations in the mobilities surrounding education, labour and citizenship. As Mountz (2010) asserts, immigration policies constitute strategic processes that seek to 'script' the identities of transnational subjects, and, further, the scripting of identities is subject to rapid transformation in the face of unintended policy consequences. As such, state authorities 'actively reproduce narratives and practices of who is welcome within their borders' (Montsion 2012, p. 470). In looking at the so-called 'crisis' through this lens, this paper reveals how political attempts to manage mobility and construct the identities of mobile subjects were, in the case of Indian students, shaped by a number of intersecting global cultural, political and economic processes 'touching down' within the policy and cultural landscape of Australia. Here, I focus on three key aspects of these processes: global labour mobilities, commercialised higher education and the subsequent development of the education-migration nexus; the marketisation of citizenship; and transnational cultural imaginaries of mobility and class. The following sections will address each of these in turn, analysing the situation of Indian students in Australia in relation to these broader processes. 


\section{Labour mobilities, commercialised universities and the education-migration nexus}

The presence of large numbers of Indian international students in Australia throughout the 2000s is clearly linked to the global phenomenon that has been termed 'the educationmigration nexus' (Robertson 2013). The education-migration nexus involves the interlinking of international education and migration policy, and in most contexts involves the granting of particular privileges towards ongoing work and residency rights to the international graduates of local higher education institutions. Although Australia was one of the first countries to implement these policies (initially granting extra immigration 'points' for international students in 1998), Western student destination countries around the world have implemented similar policies at various times, which either explicitly or implicitly favour international graduates as temporary or permanent migrants, and grant significant work rights to student visa holders. Countries with aging populations, key skills gaps and higher education sectors with large numbers of international students were most likely to adopt some form of education-migration nexus policy throughout the early 2000s, although the nature and extent of policies have varied greatly over time and across different national and regional contexts (Robertson 2013).

Globally, the education-migration nexus must be read in the context of two interconnected trends. The first is the global commercialisation of higher education and the subsequent need for many higher education providers in the West to attract high numbers of fee-paying international students, and the second is the increased mobility of labour in the context of the global race for skills among developed countries with skills shortages and ageing demographics. In Australia, higher education began to become an export market in the late 1980s and early 1990s, largely as a consequence of the decline in public funding for the tertiary sector (Marginson 2006). Australia in particular was a global leader in the ‘internationalisation' of its university sector through the enrolment of large numbers of fullfee paying international students. Its location as an English-speaking country in close proximity to Asian source countries positioned it within the 'Big Five' (Kell \& Vogl 2012) of destination countries globally. By 2009, education was famously Australia's third largest export commodity, after iron ore and coal (AEI 2010) and international students made up over $20 \%$ of the university student population (AEI 2011). As a result of this, the viability of higher education institutions became closely linked in the 2000s to their ability to continue to attract a strong share of the lucrative global market for international students. 
Australian immigration policy during this time was heavily influenced by the perceived need for a 'targeted' immigration program that provided the skilled tradespeople and knowledge sector workers needed to power the national economy. The need for a large immigration program to supply labour and sustain population has by and large had bipartisan support in Australia since the 1970s, and since the 1990s the focus has been on 'skilled' entrants (Castles \& Vasta 2004). At the end of the 1990s, providing international graduates with preferential access to permanent migration seemed like an ideal solution to put Australia ahead in the two global races for both the labour capital of skilled workers and the export capital of international student fees. Post-study migration options would attract more students to study in Australia, and as graduates they could then easily be funnelled into the labour market without issues of qualification recognition and social adjustment. The educationmigration nexus was thus heavily based on discourses of students as 'semi-finished human capital' (Khadria 2001) who had the potential to be elite ‘designer migrants’ (Ziguras \& Law 2006).

As well as post-study migration, also crucial to education-migration nexus policies and the subsequent Indian student 'crisis' was the granting of expanded work rights to those on student visas. This had the consequence of attracting more students who wanted the option of work experience while studying or needed the opportunity to gain income to balance out living and study expenses. Allowing students to work, as well as creating the possibility of earning capacity after graduation through transitioning from student to migrant, made Australian international education more attractive to many prospective students. These policies allowed Australia to retain and expand market share despite the relatively high Australian dollar for much of the late 1990s and 2000s and the high cost of living in Australia's major cities.

The development of the education-migration nexus in Australia also has to be seen in relation to Australia's position in a global market for both students and migrants. The relatively generous work and migration options Australia provided to international students were strongly linked to the ongoing competition for students and skilled labour with other Englishspeaking destination countries like Canada, New Zealand, the US and the UK, as well as to the rise in the mid- to late 2000s of Asian countries in the international education market. This regional competition threated Australia’s geographic advantage in comparison to European and North American destinations. Overall increases in the quality and prestige of 
universities in East Asia and pushes by Asian national governments to internationalise their higher education sectors (Kell \& Vogl 2012), such as Singapore’s strategy to become the 'Global Schoolhouse', meant that whether educational quality alone could keep Australia as the premier regional destination came into doubt. What Australia could offer, however, which emerging regional destinations like Singapore and Malaysia generally could not, was the opportunity for a qualification to convert into a migration outcome.

However, many competitor nations in the West, such as New Zealand, Canada and the UK, also began to offer post-study migration options in the early 2000s, putting further competitive pressure on Australia to broaden its student market. In 2004, the Vocational Education and Training (VET) sector was opened up to rapid internationalisation with VET qualifications, like university degrees, becoming linked to migration outcomes. Offering internationalised vocational as well as university-level programs was not well established in other global hubs for education export. Between 2006 and 2010, VET sector international enrolments in Australia grew by $400 \%$, with Indian students representing just under half of all international enrolments in VET during the peak of 2008-09 (DIAC 2010). This shift in the education-migration nexus to open up a new segment of the international education market also had the consequence of shifting the identities (both real and perceived) of students coming from India as less well-resourced and more lower middle class than previous waves of students, and from regional areas rather than major urban centres (Robertson 2013).

While the introduction of VET sector migration pathways was politically positioned in terms of the skills shortages in trade occupations nationally, these developments have to be understood in terms of Australia's shifting relative position as an educational destination in the global marketplace. Australia was not competitive for the so-called 'best and brightest' students from an increasingly globally significant source of skills like India, with the most elite (in terms of both class and academic achievement) Indians still largely attracted to the US and the UK as the premier English speaking destinations (Lane 2012). Australia was also facing emerging competition regionally from Asian destinations, which were often cheaper and closer to home for many students. It was these global economic conditions that led to Australia opening up the education-migration nexus as a means to secure its ongoing share of the international student market. 
The education-migration nexus in Australia by 2005 now consisted of various facets of policy: the opening up of work rights for student visas holders; the overall promise of PR after graduation; and the targeting of a less elite student demographic through the VET sector. This combination of policy mechanisms, designed to attract more students to Australia had, however, an unintended impact on local labour economies. Student visa holders in Australia became a new underclass of worker in the low skilled and service labour economies (Nyland et al. 2009). Some of these labour hierarchies also became highly ethnically stratified. Indian students, for example, although they worked across a wide variety of roles while studying, became associated mainly with convenience store clerking, taxi driving and car washing, as well as working in 'ethnic' small businesses such as Indian restaurants and grocery stores (Baas 2010, Singh 2011). The nexus thus became not just about filtering locally qualified graduates into the skilled migration program, but also about providing a 'hidden' stream of low-skilled labour through the student visa system (Dauvergne \& Marsden 2014). This labour stream was particularly visible and particularly racialised in the case of Indian students, whose labour became quite crucial to specific industries. The taxi industry in Melbourne, for example, became so dependent on mostly Indian current and former international students as drivers that a drop in Indian student enrolments after the recalibrating of nexus policies in 2011 had a serious impact on labour supply (Lucas 2011).

The limitations on student visas around hours worked and the difficulty many students had in finding mainstream employment led to both ‘semi-compliance’ (Ruhs \& Anderson 2010) in the labour market and increased vulnerability of students to exploitation by employers (Nyland et al. 2009). These labour market positions did not magically dissipate to make way for skilled roles once students graduated - in fact, there is significant evidence that it was often difficult for former students to gain skilled work (Gribble \& Blackmore 2012) and many had to take on any job available in order to repay study debts and finance ongoing living costs (Robertson 2013, Robertson \& Runganakailoo 2013). These labour market processes led to the stereotypical trope, increasingly common as a cultural referent in Melbourne and Sydney across the 2000s, of the Indian taxi driver with a prestigious local MBA.

The introduction of the VET sector into the nexus in 2004, which placed skilled trades like hairdressing, aged care and cookery as pathways to PR, also complicated the transnational labour identities and 'desirability' of students, particular for Indian students who represented 
much of the growth in VET sector enrolments. Although positioned as 'skilled' roles by the mobility regime because of labour shortages in these areas, these trade pathways did not have the cultural status, either in India or Australia, of more 'white collar' skilled occupations, particularly when compared to previously popular migration pathways for Indians through fields such as IT, medicine and accounting. The fact that VET programs were cheaper and shorter than university degrees, yet still provided access to PR, also attracted many students who were previously on more professional career trajectories to change to trade training, regardless of whether they were interested in actually practising the trade (Robertson 2013, Robertson \& Runganakailoo 2013).

The position of students within Australian labour markets thus speaks to emerging complexity around global labour mobilities. Classical theories of immigration and labour markets, and a great deal of existing empirical research, tend towards a simplistic duality of unskilled (and often undocumented) migrants working in the lowly paid 'second' sector and skilled knowledge workers with flexible and frictionless mobility occupying professional positions (Samers 2009). Indian students in Australia, in contrast, exemplify the fuzziness and the complexity around skills and qualifications as social values rather than inherent truths (Dauvergne \& Marsden 2014), and as characteristics whose value can vary under dynamic regimes of mobility. Indian students also exemplify the blurriness of the boundaries around established categories of mobile labour globally, with permanent/temporary or skilled/unskilled no longer binary categories of migrant type, but rather constructed and dynamic identities that shift according to policy transmutations and migrants' own agencies.

Within labour hierarchies in the host country such identities intersect in different ways with language, class, race and ethnicity in terms of how workers' value and power are subsequently constructed, both within specific workplaces and within broader labour geographies (Datta \& Brickell 2009, Cook, Dwyer \& Waite 2011). Through particular modes of the management of mobility, particular structural obstacles in the local labour market, and also through migrants' own agencies, skills and knowledge might not necessarily be mobilised in expected ways and the status of a visa category (e.g. student, skilled migrant) does not necessarily reflect the type of work that mobile subjects undertake or the type of labour subjectivities that become ascribed to them in the local cultural imagination. Indian students, for example, played a complex 'double role’ as workers in Australia - as students they were the cheap 'fuel' for the secondary economy yet they were expected to become the 
future 'in demand highly skilled workers'. Their inability to transition seamlessly into the skilled workforce upon graduation led to significant critiques of both policy and of students' intentions within both media and academia (see for example Garnaut 2006; Birrell, Healy \& Kinnaird 2007).

It was through these complex and dynamic processes of labour subjectivity-making that student-migrants moved from being seen as ‘designer migrants’ (Ziguras \& Law 2006) to ‘backdoor migrants’ (Colebatch 2010, Murphy 2010). From around 2005, international students seeking PR were no longer seen as desirable migrants but problematic and opportunistic intruders who did not represent the 'right' kind of skilled labour (Robertson 2013). Indian students in particular, with their racialised visibility as unskilled labour in the community and in the media, came to particularly exemplify this discourse of 'problematic' mobility. As the education-migration nexus came under fire in the late 2000s, subsequent policy moves sought to further manage the transition from student to worker, generally implementing further steps in the student-to-migrant journey that would act to mould more 'desirable’ worker identities. In 2007, 18 month temporary work visas for graduates were introduced, replacing many of the direct pathways from student visas to PR, and in 2008 the 'Professional Year' program was introduced for accounting, IT and engineering graduates to gain professional skills and experience before applying for residency. In 2010, the Migration Occupations in Demand List (MODL) was scrapped altogether and replaced by a Skilled Occupations List (SOL), which focused much more on highly technical professional skills than on trade occupations. This effectively cut off direct pathways from VET education to permanent residency. These policies were at face value a means to 'recalibrate' an immigration system that was seen in economic logics to have become more 'supply driven' than 'demand driven'. Yet they were also inherently designed to 'remould' desirable and selfreliant migrant-workers, rather than to actually address the fundamental issues of labour market exploitation and discrimination embedded within education-migration nexus processes.

\section{The marketisation of citizenship}

The education-migration nexus can also be seen as an implicit part of transformations in citizenship both in Australia and in the context of global circuits of mobility. The nexus meant that for the first time since Federation there was a large population of noncitizen 
residents in Australia, many with uncertain temporal horizons. Indian students in particular typified the increasing blurriness of boundaries between temporary/permanent and sojourner/settler because, although they entered Australia with temporary student visas, many were motivated to use this as a 'stepping stone' to PR and citizenship. These staggered migration trajectories are not entirely novel when viewed in historical context. The earliest migration circuits between India and Australia, for example, in the late $19^{\text {th }}$ and early $20^{\text {th }}$ centuries, consisted of Sikh sojourners who moved back and forth between wage labour in Australia and their natal villages in the Punjab (Dusenbury 2005). However, a settler-citizen paradigm dominated Australian immigration norms and processes for much of the $20^{\text {th }}$ century, and particularly since the post-war era (Robertson 2014). This paradigm was significantly disrupted by the influx of Indian students on 'staggered pathways', which both shaped and were shaped by increasingly neoliberal logics within ideologies and processes of citizenship in Australia.

The neoliberal transformation of citizenship is a global trend in many migrant-receiving countries. It includes the increase in highly quantified assessments of migrants' skills, qualifications and biopolitical characteristics (often through 'points tests'); the rise of 'investor migrant' schemes; the reduction in family reunion and humanitarian resettlement; and the ability for temporary workers to gain permanency through the performance of particular kinds of 'value' as labour, in which labour power is 'exchanged' for further rights in often highly unequal transactional processes (Lee \& Pratt 2010, Rajkumar et al. 2012, Walsh 2011). The neoliberalisation of processes of national membership and belonging have been referred to in the literature as 'contractualised' citizenship (Somers 2008) or 'earned' (Van Houdt et. al. 2011) citizenship. In the specific context of Indian students in Australia during the heyday of the education-migration nexus, however, I refer to the expansion of neoliberal citizenship logics as the 'marketisation of citizenship'. This reflects how education-migration nexus processes involved forms of contract and exchange but also processes of consumption in relation to citizenship.

International students in Australia, as well as other temporary migrants, have to 'earn' citizenship through investments in time, money and labour as well as through the performance of 'desirable' migrant subjectivities that translate within the immigration regime's quantified assessment of migrant value. The characteristics of desirability are biopolitical (for example, age and health) as well as related to specific types of human capital 
(such as qualifications and work experience). Consumption also relates to the marketisation of citizenship, with the economic contribution of international students through student fees and consumer spending while in Australia also forming an implicit basis for the right to ongoing membership. The rise of a transnational industry of migration and education agents (an industry which is particularly prolific in India) furthers the marketisation of citizenship, in the sense that those with the financial resources to engage agents and lawyers are able to use this to their advantage in the citizenship 'market'.

Citizenship 'exchanges' such as these, in which migrants have to 'earn' or 'buy' their way to citizenship, often involve different forms of violence upon the bodies of migrants. Lee and Pratt (2010) provide two very clear examples of this in the context of the Filipino diaspora: the military service (and sometimes the death in duty) of undocumented migrants in the US as a pathway to 'earn' citizenship for themselves and their families, and the 'indentured servitude' of domestic workers in the Live-in Caregiver Program in Canada where female migrants exchange two years of intensive care labour to gain a permanent status. While the case of Indian students in Australia is perhaps less extreme than these examples, Indian students in the years surrounding the 'crisis' had to invest significantly, both financially and emotionally, into the quest for PR/citizenship. This was a burden often taken on by the family unit, with loans for tuition and visa application fees often creating a transnational system of family debt that students were then expected to pay back once legal membership in Australia was achieved (Baas 2006, Neilson 2009). The time spent away from family and the long hours working at 'violent and precarious' (Verma 2013) jobs, as well as the time invested in study and the various costs of living were also investments expected to 'pay off' with the achievement of PR. Students limited financial agency meant that they lived and worked in some of the 'some of the struggle spaces of Australian cities' (Dunn, Pelleri \& Maeder-Han, 2011, p. 84), which left them vulnerable to both workplace exploitation and racist violence. The marketisation of citizenship for Indian students thus functioned as a highly unequal and highly unstable process of exchange, with the state always holding the power to change requirements after students had already invested considerable amounts of time, money and labour into the dream of PR. Significant changes in nexus policies in 2010, for example, part of a post-crisis policy backlash, left 122,149 VET sector student visa holders without any hope of achieving a return on their investment in fees and labour in the form of a migration outcome (Verma 2013), and little chance of being able to use their qualifications if they returned home (Robertson \& Runganakailoo 2013). 
The highly unequal processes of marketised citizenship described above also further complicated the subjectivities surrounding international students, this time in relation to citizenship. Once able to be neatly boxed as transient consumers who arrived with the primary motivation to consume Australian education and stay only for the duration of this consumption, student subjectivities became far more complex. As Deumert et al. (2005, p. 329) notes 'as well as being educational service beneficiaries, cross-border students are migrants, workers, consumers and human beings'. The problem of the commercialisation of education and the education-migration nexus then became around reconciling the consumer (whose welfare and satisfaction is largely the responsibility of the service provider) with the potential or partial citizen, who is a member of the community, an active participant in the labour force, and a potential permanent settler (which implies a broader scope of responsibility for their rights and welfare involving both the community and the state).

The violence against Indian students and the subsequent political actions (both the 'peace rallies' in Melbourne and Sydney in 2009 and the taxi driver protests in Melbourne in 2008) were some of the events that put these complex and shifting citizenship subjectivities into sharp relief. The 'marketisation' model of citizenship clashed here with existing ideologies of liberal inclusiveness, universal human rights, and multicultural fairness. Over the first decade of the 2000s there was thus a shift, in both public attitudes and policy, to international student welfare. Academic work reframed student welfare from a customer satisfaction framework to engage with ideas of civil society, global citizenship, and universal human rights (see, for example Forbes-Mewett 2005 and Deumert et al. 2005), and various levels of local, state and federal government also began, in a limited way, to treat students as partial citizens rather than transient consumers (Robertson 2013). These expansions in understandings of student welfare and citizenship were, however, still frequently undercut by marketisation logics, with both government agencies and student advocacy groups frequently linking the protection of students' rights with the protection of Australia's 'export' market for education (Robertson 2011).

The marketisation of citizenship is also closely linked not just to local and national processes of rights and belonging, but also to global hierarchies of citizenship (Lee 2008, Aas 2013) which place Australian citizenship and permanent residency as more valuable to the mobile subject than many non-Western citizenships, including Indian citizenship. The Australian 
passport has global 'mobility value' because of its relative neutrality as a Western passport, meaning that Australian passport holders often have fewer visa requirements and more general fluidity across borders, especially into other developed nation-states. For Indian students, Australian citizenship has additional mobility value in that it also allows dual citizenship, which gives Indian nationals who naturalise the advantage of access to Overseas Citizenship of India (OCI) status. Global hierarchies of citizenship, which are constructed through an international system of mobility that privileges certain national citizenships over others for people on the move, as well as the more intangible social and cultural 'status' of the Western or dual citizenship, make Australian citizenship 'global' in a way that Indian citizenship is not. For Indian students in Australia therefore, obtaining Australian citizenship could signify settlement in and belonging to Australia, but also strongly symbolise the capacity for transnational social capital and ongoing global mobility (Baas 2010b), a type of ‘flexible citizenship’ (Ong 2006).

\section{Class and cultural imaginaries of mobility}

As Baas (2010a) has shown, Indian student journeys were not imagined through frameworks of 'migration' or 'settlement' or even of two country 'transnationalism' but rather of ongoing intra- and international mobility between India, Australia and various other countries - a process of becoming 'global' or 'mobile’ rather than becoming ‘Australian’ or 'Western'. Thus, despite the deep significance of the citizenship ideologies and nexus policies described above, cultural imaginaries of mobility were arguably an equally important driver of the presence of large numbers of Indian students in Australia in the first decade of the $21^{\text {st }}$ century. The cultural imaginaries of these students were, as Baas (2010a) has clearly shown in his anthropological work, highly significant in shaping their desires for overseas education, work experience and ultimately, PR or citizenship. Time spent in the West has become a highly significant rite of passage for many middle-class Indian young people. This is driven not just by the tangible opportunity to accumulate particular types of social and cultural capital, like language skills, international networks and Western passports, but also by a less tangible 'imaginary' of what it means to be an 'upwardly mobile' young person in India today. Within this imaginary international higher education becomes 'imbued with mediated meanings’ (Caluya, Probyn \& Vyas 2011, p. 88) and serves as a class marker (Rizvi 2005) as well as ‘a marker of modernity’ (Caluya, Probyn \& Vyas 2011, p. 88). 
The existing post-colonial cultural relationship between India and Australia, as well as the fact that Australia has been a key site of settlement for the Indian diaspora since the 1970s, form part of the imaginary of Australia as a specific destination in the West for the mobile, global young Indian. These existing cultural imaginaries were, and still are, intensified and exploited by the Australian government and higher education sector, whose direct marketing towards India is also a key part of nexus processes. Intensifying imaginaries of educational mobility has also proved profitable for the capitalist sector of 'middle-men' in both Australia and India who facilitate mobility, including education and migration agents, accommodation brokers, private colleges, and loan sharks. Both the desire and the opportunity for international education have also diffused rapidly over the last few decades across a broader segment of the Indian middle class in a general national context of increased social mobility. While overseas education was once only the domain of a small section of the elite, urban upper middle class (Gillan, Damachis \& McGuire 2003), Australian education in particular became achievable for a far less elite middle class of peri-urban or semi-rural Indian families with the opening up of the VET sector (Baas 2007). Aspirations for social mobility through becoming a 'global' Indian were enabled through less costly course options, opportunities for earning capacity in Australia during and after study, and increased (and aggressively marketed) borrowing options to finance overseas study through banks and other formal and informal lenders.

The desirability of migrants to the nation-state is inherently linked to class privilege (Sparke 2009). Class thus played a key role in the shifting desirability/undesirability of Indian students as mobile subjects. Previous waves of elite students were seen as self-sufficient and highly resourced, and therefore unproblematic. The post-2004 emerging class of non-elite Indian students were generally painted in the media as either opportunistic and untrustworthy 'backdoor migrants' or hapless victims of an exploitative system and racist culture (Robertson 2013). A class division was also present within the increasingly heterogeneous population of Indian students that reflected Australian discursive anxieties about good versus bad migrants. Baas (2014) notes, for example, that members of 'older' cohorts of Indian students saw the post-2004 cohort as partially to blame for the violence for being 'poorly adjusted' and not speaking English well. As Caluya, Probyn and Vyas (2011, p. 90) explain 'the same Indian who operates as a cultural Other for the middle class white Australian becomes a class-based Other for the good Indian student. This “Permanent Residency 
oriented student” is then a threat to the nation of India in general, and particularly to the “good Indian student”.'

The class identities of students also became important discursively, although in somewhat paradoxical forms, in media constructions of the violence. On the one hand, Indian students were positioned as vulnerable because they were travelling to unskilled jobs late at night and living and commuting in socio-economically deprived suburban areas. Yet they were also positioned by police spokespeople as 'soft targets' because they showed overt signs of wealth, such as expensive mobile phones and iPods (Baas 2014). These discursive constructions of 'desirable/undesirable’ and 'vulnerable' migrants as classed subjects neglect the complex agencies and motivations of Indian students from varied class backgrounds, and obscure the role of the immigration regime itself in the construction of migrant subjectivities.

As I have argued above, the 'desirability' of Indian students as mobile subjects shifted in the Australian cultural imaginary from 'designer migrants' to ‘backdoor migrants'. This was closely linked to particular media and policy discourses, but it can also be understood in relation to the contrasting cultural imaginaries of mobility that already existed in Australia and India. Indian imaginaries of ongoing mobility and the accumulation of flexible citizenship clashed with embedded Western ideas of middle-class young people studying and working 'abroad'. For most middle-class Australians, time spent overseas is a common 'rite of passage' for young people, but constructions of this mobility (such as 'gap years' and 'student exchanges') centre more on ideas of self-actualisation, professional development and leisure travel (Simpson 2005; Wilson \& Fisher 2009; Hirschorn \& Hefferon 2013) than on labour migration or the accumulation of flexible citizenship. These contrasting imaginaries made a Western audience see the actions of Indian students using education as a stepping stone to PR as suspect - positing them as 'backdoor migrants' who were not genuinely interested in education for education's sake. Yet this public attitude tended to ignore the fact that international education had not been instrumentalised as 'earning' a migration outcome by Indian students themselves. Rather, it had been instrumentalised by the market-based logics that dominated the Australian higher education and immigration regimes (Caluya, Probyn \& Vyas 2011), and further intensified by the 'brokerage’ industry - including peak national bodies like Australian Education International, as well as the raft of agents and recruiters working for and with Australian education providers. The development of the 'PR 
factory' college and the 'PR motivated student' were thus the consequence of these systems and industries, rather than some moral failing or duplicity of students themselves.

\section{Conclusions}

In many ways the Indian student 'crisis’ exemplifies Castles' (2004) thesis of the 'unintended consequences' of immigration policy. Meant to slip seamlessly into the labour market as 'designer migrants', Indian students instead proved to defy, through both structural pressures and their own agencies, the intended 'frictionless' (Baldassar \& Pyke 2014) and neoliberalised outcomes of the education-migration nexus. They faced significant vulnerabilities while in Australia as 'citizens-in-waiting', as they were subject to the tangible racist violence of the streets as well as the systemic violence (Žižek 2009) wrought by labour exploitation and the precarious status created by migration policy. The consequences also reached far beyond individual student migrants - the crisis sparked a series of critiques around the quality of the Australian education industry, Australia's commitment to multiculturalism, and the nature of Australia's bilateral relationship to India as an emerging regional power.

Rather than looking at the localised debates on race and violence sparked by the crisis, this paper has sought to position the Indian student crisis itself as a consequence of particular transnational and global processes, and particular modes of the national governance of mobility that are embedded within these processes. It has asked what the supposed crisis tells us about the ways in which global economic processes, national immigration regulations, and varied cultural imaginaries of mobility shape particular kinds of mobile subjectivities at different times. In particular, I have focused on three key processes that shaped the presence and position of Indian students within Australian society leading up to the crisis: the education-migration nexus as an outcome of the global commercialisation of higher education and the globalisation of labour; the marketisation of citizenship; and the contested cultural imaginaries of mobility and class in both Australia and India. These processes intersected to lead to highly dynamic national policies around the management of mobility which made and remade Indian students as desirable and then undesirable subjects.

The Indian student crisis was a moment of reflection for Australia on its still troubled relationship with racial difference in spite of its nearly 40-year legacy of official 
multiculturalism. Yet, as I have tried to show, it should also remain a series of events that causes us to reflect on the way our relationship to the mobile subjects travelling and living within and across our national borders are shaped by economic and cultural forces that both transcend and are embedded within the nation-state itself. In particular, the shifting fortunes of Indian students in Australia across the 2000s should give us pause for thought on the discursive and political power of migration governance, the migration industry, the education industry and the cultural and ideological constructs around mobility, citizenship and belonging that are shaped through them.

\section{References}

Aas, K. F. 2013, 'The ordered and the bordered society: Migration control, citizenship, and the northern penal state', in K.F. Aas and M. Bosworth (eds) The Borders of Punishment: Migration, Citizenship, and Social Exclusion, Oxford University Press, Oxford, pp. 21-39. doi: http://dx.doi.org/10.1093/acprof:oso/9780199669394.003.0002

ABC News 2009, 'Police deny Indian attacks racist', ABC News, June 9th. Accessed 11/07/2014 at: http://www.abc.net.au/news/2009-06-09/police-deny-indian-attacks$\underline{\text { racist } / 1708090}$

Australian Education International 2010, International student enrolment and visa statistics. Accessed 20/03/12 at: http://aei.gov.au/AEI/Statistics/studentenrolmentandvisastatistics/Default.html

AEI 2011, Onshore higher education international students as a proportion of all onshore students by university, 2010, Research Snapshots. Accessed 23/08/14 at: https://www.aei.gov.au/research/ResearchSnapshots/Documents/International\%20stude nts\%20in\%20Australian\%20unis\%202010.pdf

Baas, M. 2006, 'Students of migration: Indian overseas students and the question of permanent residency', People and Place, vol. 14, no. 1, pp. 9-24.

Baas, M. 2007, 'The language of migration: the education industry versus the migration industry', People and Place, vol. 15, no. 2, p. 49.

Baas, M.2010a, Imagined Mobility: Migration and Transnationalism among Indian students in Australia, Anthem Press, London.

Baas, M. 2010b, 'Praying for food. Class and Indian overseas students in Australia', in G.T. Bonifacio and V.S. Angeles (eds) Gender, Religion, and Migration: Pathways of Integration, Rowman \& Littlefield, Maryland, pp. 71-93. 
Baas, M. 2014, 'Victims or profiteers? Issues of migration, racism and violence among Indian students in Melbourne', Asia Pacific Viewpoint, vol. 55, no. 2, pp. 212-225. doi: http://dx.doi.org/10.1111/apv.12046

Baldassar, L., \& Pyke, J. 2014, 'Intra-diaspora knowledge transfer and 'new' Italian migration', International Migration, vol. 52, no. 4, pp.128-143. doi:

http://dx.doi.org/10.1111/imig.12135

Birrell, B., Healy E. \& Kinnaird, B. 2007, 'Cooks galore and hairdressers aplenty', People and Place, vol. 15, no. 1, pp. 30-44.

Caluya, G., Probyn, E. \& Vyas, S. 2011, ' "Affective eduscapes": the case of Indian students within Australian international higher education', Cambridge Journal of Education, vol. 41, no. 1, pp. 85-99. doi: http://dx.doi.org/10.1080/0305764X.2010.549455

Castles, S. 2004, 'The factors that make and unmake migration policies', International Migration Review, vol. 38, no. 3, pp. 852-884. doi: http://dx.doi.org/10.1111/j.17477379.2004.tb00222.x

Castles, S. \& Vasta, E. 2004, 'Australia: New conflicts around old dilemmas', in W. Cornelius (ed.) Controlling Immigration: A Global Perspective, Stanford University Press, Stanford, pp. 141-173.

Colebatch, T. 2010, 'Economic slump hits population', The Age, June 5th. Accessed 17/08/2012 at: http://www.theage.com.au/national/economic-slump-hits-population20100604-xkqw.html.

Cook J., Dwyer, P. \& Waite, L. 2011, 'The experiences of Accession 8 migrants in England: Motivations, work and agency', International Migration, vol. 49, no. 2, pp. 54-79. doi: http://dx.doi.org/10.1111/j.1468-2435.2009.00595.x

Datta, A. \& Brickell, K. 2009, ' "We have a little bit more finesse, as a nation": Constructing the Polish worker in London's building sites', Antipode, vol. 41, no. 3, pp. 439-464. doi: http://dx.doi.org/10.1111/j.1467-8330.2009.00682.x

Dauvergne, C. \& Marsden, S. 2014, 'The ideology of temporary labour migration in the postglobal era', Citizenship Studies, vol. 18, no. 2, pp. 224-242. doi: http://dx.doi.org/10.1080/13621025.2014.886441

Deumert, A., Marginson, S., Nyland, C., Ramia, G. \& Sawir, E. 2005, 'Global migration and social protection rights: the social and economic security of cross-border students in Australia', Global Social Policy, vol. 5, no. 3, pp. 329-352. doi: http://dx.doi.org/10.1177/1468018105057415 
Department of Immigration and Citizenship (DIAC) 2010, Student Visa Program Trends2003-4 to 2009-10. Accessed 16/05/14 at:

http://www.immi.gov.au/media/statistics/study/_pdf/student-visa-program-trends-200910.pdf

Dunn, K., Pelleri, D. \& Maeder-Han, K. 2011, 'Attacks on Indian students: the commerce of denial in Australia', Race \& Class, vol. 52, no. 4, pp. 71-88. doi: http://dx.doi.org/10.1177/0306396810396603

Dusenbery, V.A. 2005, 'Sikh positionings in Australia and the diaspora concept', in $\underline{\mathrm{M}}$. Ember, C. R. Ember, and I. Skoggard (eds), Encyclopedia of Diasporas. Immigrant and Refugee Cultures Around the World, Springer, New York, pp. 485-491. doi: http://dx.doi.org/10.1007/978-0-387-29904-4_49

Forbes-Mewett, H. 2005, 'The concept of security and its relevance to the international education market', ISANA International Education Association. Accessed 25/09/14 at: http://www.isana.org.au/files/200629155924_conceptofsecurity.pdf

Foster, H. \& Foster J. 1999, "'Caught in the crack": Stereotypes of South Asians in Australian children's and adolescent literature’, Bookbird, vol. 37, no. 2, pp. 30-35.

Garnaut, J. 2006, 'Universities being used as immigration "factories"', The Sydney Morning Herald, March 29th. Accessed 29/07/10 at: http://www.smh.com.au/news/national/unisused-as-immigration-factories/2006/03/29/1143441215915.html

Gillan, M., Damachis, B. \& McGuire, J. 2003, 'Australia in India: commodification and internationalisation of higher education', Economic and Political Weekly, pp. 13951403

Gribble, C. \& Blackmore, J. 2012, 'Re-positioning Australia's international education in global knowledge economies: implications of shifts in skilled migration policies for universities', Journal of Higher Education Policy and Management, vol. 34, no. 4, pp. 341-354. doi: http://dx.doi.org/10.1080/1360080X.2012.689181

Hirschorn, S. \& Hefferon, K. 2013, 'Leaving it all behind to travel: Venturing uncertainty as a means to personal growth and authenticity', Journal of Humanistic Psychology, vol. 53, no. 3, pp. 283-306. doi: http://dx.doi.org/10.1177/0022167813483007

International Education Association of Australia (IEAA) 2012a, Submission to the International Education Advisory Council: International Education Association of Australia. Accessed 3/9/14 at:

https://aei.gov.au/IEAC2/Submissions(IEAC)/Documents/37.\%20IEAA.pdf 
IEAA 2012b, Discussion Paper for the Development of International Education Strategy for the Australian International Education Advisory Council. Accessed 3/9/14 at: https://aei.gov.au/IEAC2/Consultation(IEAC)/Documents/InternationalEducationAdvis oryCouncilDiscussionPaper.pdf

Jamieson, A. 2010, 'Murder, racism and Melbourne', Crikey, January 7th. Accessed 09/07/2014 at: http://www.crikey.com.au/2010/01/07/murder-racism-and-melbourne-acrikey-wrap/

Kell, P. \& Vogl, G. 2012, International students in the Asia-Pacific: Mobility, risks and global optimism, Springer, Sydney. doi: http://dx.doi.org/10.1007/978-94-007-2897-4

Khadria, B. 2001, 'Shifting paradigms of globalisation: The twenty-first century transition towards generics in skilled migration', International Migration, vol. 39, no. 5, pp. 4571. doi: http://dx.doi.org/10.1111/1468-2435.00171

Knight, S. 2011, Strategic Review of the Student Visa Program. Accessed 07/05/13 at: http://www.immi.gov.au/students/_pdf/2011-knight-review.pdf

Lane, B. 2012, 'More Indian students coming to campus', The Australian, August 29th

Lee, C. T. 2008, 'Undocumented workers' subversive citizenship acts', Peace Review, vol. 20, no. 3, pp. 330-338. doi: http://dx.doi.org/10.1080/10402650802330170

Lee, C. T. \& Pratt, G. 2012, 'The spectacular and the mundane: racialised state violence, Filipino migrant workers, and their families', Environment and Planning A, vol. 44, no. 4, pp. 889-904. doi: http://dx.doi.org/10.1068/a4448

Lucas, C. 2011, 'Driver shortage for taxis as Indian student numbers fall', Drive.Com.au, February 10th. Accessed 02/0414 at: http://www.drive.com.au/roads-and-traffic/drivershortage-for-taxis-as-indian-student-numbers-fall-20110209-1an3l.html

Marginson, S. 2006, 'Australian universities in a global context', Paper presented at the Business and Higher Education Roundtable (BHERT) Higher Education Summit, Melbourne, June, 7th.

Mason, G. 2012, ' "I am tomorrow": Violence against Indian students in Australia and political denial', Australian \& New Zealand Journal of Criminology, vol. 45, no. 1, pp. 4-25. doi: http://dx.doi.org/10.1177/0004865811431330

Montsion, J. M. 2012, 'When talent meets mobility: un/desirability in Singapore's new citizenship project', Citizenship Studies, vol. 16, nos. 3-4, pp. 469-482. doi: http://dx.doi.org/10.1080/13621025.2012.683259 
Mountz, A. 2010, Seeking Asylum. Human Smuggling and Bureaucracy at the Border, University of Minnesota Press, Minneapolis. doi: http://dx.doi.org/10.5749/minnesota/9780816665372.001.0001

Murphy, K. 2010, 'Crackdown on skilled migrants', The Age, February 8th. Accessed 07/07/14 at: http://www.theage.com.au/small-business/crackdown-on-skilled-migrants20100208-nmru.html

Neilson, B. 2009, 'The world seen from a taxi: Students-migrants-workers in the global multiplication of labour', Subjectivity, vol. 29, no. 1, pp. 425-444. doi: http://dx.doi.org/10.1057/sub.2009.23

Nyland, C., Forbes-Mewett, H. et al. 2009, 'International student workers in Australia: A new vulnerable workforce', Journal of Education and Work, vol. 22, no. 1, pp. 1-14. doi: http://dx.doi.org/10.1080/13639080802709653

Ong, A. 2006, 'Mutations in citizenship', Theory, Culture \& Society, vol. 23, nos. 2-3, pp. 499-505. doi: http://dx.doi.org/10.1177/0263276406064831

Rajkumar, D. \& Berkowitz, L. et al. 2012, 'At the temporary-permanent divide: how Canada produces temporariness and makes citizens through its security, work, and settlement policies', Citizenship Studies, vol. 16, nos. 3-4, pp. 483-510. doi: http://dx.doi.org/10.1080/13621025.2012.683262

Rizvi, F. 2005, 'International education and the production of cosmopolitan identities', RIHE International Publication Series, vol. 9, pp. 77-92

Robertson, S. 2011, 'Cash cows, backdoor migrants, or activist citizens? International students, citizenship, and rights in Australia', Ethnic and Racial Studies, vol. 34, no. 12, pp. 2192-2211. doi: http://dx.doi.org/10.1080/01419870.2011.558590

Robertson, S. 2013, Transnational Student-Migrants and the State: The Education-Migration Nexus, Palgrave MacMillan, Basingstoke. doi: http://dx.doi.org/10.1057/9781137267085

Robertson, S.2014, 'Time and temporary migration: The case of temporary graduate workers and working holiday makers in Australia', Journal of Ethnic and Migration Studies, vol. 40, no.12, 1915-1933. doi: http://dx.doi.org/10.1080/1369183X.2013.876896

Robertson, S.\& Runganaikaloo, A. 2013, 'Lives in limbo: Migration experiences in Australia's education-migration nexus', Ethnicities, vol. 14, no. 2, pp. 208-226. doi: http://dx.doi.org/10.1177/1468796813504552 
Ruhs, M. \& Anderson, B. 2010, 'Semi-compliance and illegality in migrant labour markets: an analysis of migrants, employers and the state in the UK', Population, Space and Place, vol. 16, no. 3, pp. 195-211.

Samers, M. 2009, Migration, Routledge, London.

Simpson, K. 2005, 'Dropping out or signing up? The professionalisation of youth travel', Antipode, vol. 37, no. 3, pp. 447-469. doi: http://dx.doi.org/10.1111/j.0066$\underline{4812.2005 .00506 . x}$

Singh, S. 2011, 'Indian students in Melbourne: Challenges to multiculturalism', Journal of Intercultural Studies, vol. 32, no. 6, pp. 673-689. doi: http://dx.doi.org/10.1080/07256868.2011.618110

Somers, M. R. 2008, Genealogies of Citizenship: Markets, Statelessness, and the Right to Have Rights, Cambridge University Press, Cambridge.

Sparke, M. 2009, 'On denationalization as neoliberalization: biopolitics, class interest and the incompleteness of citizenship', Political Power and Social Theory, vol. 20, pp. 297-300. doi: http://dx.doi.org/10.1108/s0198-8719(2009)0000020017

Spolc, P. \& Lee, M. 2009, 'Indian students in Australia: victims of crime, racism or the media?' Paper presented at 20th ISANA International Education Conference, Canberra.

Van Houdt, F., Suvarierol, S. \& Schinkel, W. 2011, 'Neoliberal communitarian citizenship: Current trends towards 'earned citizenship'in the United Kingdom, France and the Netherlands', International Sociology, vol. 26, no. 3, pp. 408-432. doi: http://dx.doi.org/10.1177/0268580910393041

Verma, S. 2013, 'Pathways to illegality, or "what happened to the International students?"' Mutinyzine, July 11th. Accessed 05/08/14 at: http://mutinyzine.blog.com/2013/07/11/pathways-to-illegality

Walsh, J. P. 2011, 'Quantifying citizens: neoliberal restructuring and immigrant selection in Canada and Australia', Citizenship Studies, vol. 15, nos. 6-7, pp. 861-879. doi: http://dx.doi.org/10.1080/13621025.2011.600135

Wilson, J., Fisher, D. et al. 2009, 'The OE goes 'home': Cultural aspects of a working holiday experience', Tourist Studies, vol. 9, no. 1, pp. 3-21. doi: http://dx.doi.org/10.1177/1468797609360590

Ziguras C. \& Law, S. F. 2006, 'Recruiting international students as skilled migrants: the global 'skills race' as viewed from Australia', Globalisation, Societies and Education, vol. 4, no. 1, pp. 59-76. doi: http://dx.doi.org/10.1080/14767720600555087

Žižek, S. 2009, Violence: Six Sideways Reflections, Profile Books, London. 